\title{
DEPOSIT PROTECTION IN A PATERNALISTIC STATE: THE RUSSIAN CASE
}

\author{
Andrei VERNIKOV, \\ Doct. Sci. (Econ.), Senior Researcher, \\ Institute of Economics, Russian Academy of Sciences, \\ Moscow, Russian Federation, \\ e-mail:vernikov@inecon.ru
}

Citation: Vernikov, A. (2020). Deposit protection in a paternalistic state: The Russian case. Terra Economicus, 18(1), 28-42. D0I: 10.18522/2073-6606-2020-18-1-28-42

This paper places the institution of bank deposit protection in the context of government paternalism. I apply the theories of deposit insurance, merit goods, patronized goods, government paternalism, and institutional change to the analysis of the Russian case. The paper relies on statistical data from the Central Bank of Russia, Deposit Insurance Agency, and Rosstat. The findings are five-fold: (1) There is similarity between theoretical justification for government paternalism and intervention in household savings and the humanitarian sphere; (2) Deposit protection fits well the Russian institutional setup, due to its paternalistic nature; (3) The public choice-driven purpose of government intervention in household savings may change in the process. Patronage of small savers becomes camouflage for protection of private banks; (4) Deposit guarantee redistributes wealth from the public sector to the private one; (5) Deposit guarantee hinders the evolution of the market discipline and responsibility while fostering opportunistic behavior patterns among depositors and banks. The research implication of the paper is that, in the absence of strict eligibility criteria for merit goods, one can identify goods and services that probably do not belong there but sneak into that category by means of a manipulated public choice and thus get similar treatment with traditional humanitarian sectors. The policy implication is that the authorities might wish to tackle opportunistic behavior at source, i.e. by amending the parameters of the deposit insurance scheme.

Keywords: merit goods; paternalism; state; institutional change; government; public choice; banks; deposit guarantee; Russia; redistribution

JEL codes: B52, D78, E65, G21, G28, H41 


\title{
СТРАХОВАНИЕ ВКАААОВ В ПАТЕРНААИСТСКОМ ГОСУААРСТВЕ (НА ПРИМЕРЕ РОССИИ)
}

\author{
Андрей Владимирович ВЕРНИКОВ, \\ доктор экономических наук, ведущий научный сотрудник, \\ Институт экономики РАН, \\ г. Москва, Российская Федерация, \\ e-mail:vernikov@inecon.ru
}

\begin{abstract}
Цитирование: Верников, А. В. (2020). Страхование вкладов в патерналистском государстве (на примере России) // Terra Economicus, 18(1), 28-42. DOI: 10.18522/2073-6606-2020-18-1-28-42

Институт страхования вкладов рассматривается в статье с точки зрения государственного патернализма. На примере России данный эмпирический материал проанализирован с применением подходов из теорий страхования вкладов, мериторных благ, опекаемых благ, государственного патернализма и конструирования институтов. Использованы статистические данные Банка России, Агентства по страхованию вкладов и Росстата. Основные результаты исследования можно свести к следующим пяти пунктам: (1) Есть параллели между теоретической аргументацией в пользу государственного патернализма и вмешательства в сферу частных сбережений граждан, с одной стороны, и в гуманитарную сферу, с другой. (2) Защита вкладов государством хорошо вписывается в комплекс базовых российских институтов благодаря своей патерналистской направленности. (3) В процессе реализации государственного патернализма его цель, поддержанная общественным выбором, меняется: защита уязвимых категорий вкладчиков уступает место адресному протекционизму частных банков и верхних слоёв среднего класса. (4) Страхование вкладов имеет тенденцию перераспределять общественное благосостояние в пользу частного сектора. (5) Страхование вкладов тормозит развитие рыночных институтов дисциплины и ответственности, стимулируя при этом оппортунистические модели поведения как среди вкладчиков, так и среди банков. С теоретической точки зрения, статья показывает, что критерии отнесения того или иного товара или услуги к категории мериторных или опекаемых не столь чёткие. В этих условиях некоторым благам, имеющим сомнительные основания для причисления к данной категории, тем не менее удаётся в эту категорию попасть с помощью манипуляции общественным выбором и получить благодаря этому привилегии, сравнимые с теми, которыми пользуются гуманитарные сектора. С точки зрения экономической политики, автор считает, что стимуль к вредному и опасному для общества оппортунистическому поведению нужно устранять непосредственно «у источника», т.е. путём изменения параметров действующей системы защиты вкладов.
\end{abstract}

Ключевые слова: мериторные блага; патернализм; государство; конструирование институтов; общественный выбор; банки; страхование вкладов; Россия; перераспределение 


\section{Introduction}

The purpose of this text article is to place the institution of deposit insurance ${ }^{1}$ in the context of merit goods theory and paternalistic government policies. Merit goods theory posits that society as a whole may have needs and interests that cannot be reduced to those of its members. The government in its role of public interest defender, can pursue a desirable level of consumption of certain goods and services regardless of insufficient current market demand for them. Those specific goods and services are called merit goods (Musgrave, 1987). Merit goods primarily relate to areas of human development, namely health care, education, culture and fundamental research. A closely related theory deals with patronized goods or goods and services concerning which there is a public interest, or whose production and consumption is related to government activity (Rubinstein, 2016).

The reason why I place household savings in the same context with merit goods and patronized goods is that I expect to find similarity in the theoretical justification for, and the actual evidence of, government paternalism and intervention. Paternalism is the interference of the government, motivated by a claim that citizens will be better off or protected from harm (Dworkin, 2019).

The sphere of household savings, at first sight, appears to be irrelevant to the concept of merit goods because it embraces private agents in a competitive industry, each pursuing own individual benefit and utility. Empirical evidence, however, compels reconsidering this intuitive judgment. The institution of private deposits protection under the auspices of the government has become widespread all over the world. One hundred twelve countries had an explicit deposit insurance scheme by year-end 2013 (Demirgüç-Kunt et al., 2015: 76), and the number keeps growing. Deposit protection has a significant social dimension due to its vast outreach that involves every individual having a bank account or deposit, i.e. a substantial part of the adult population. Bank instability can potentially increase social tension and, in extreme cases, lead to political turmoil. Public interest is invoked when a decision concerning deposit insurance is made. Similar to what happens in the humanitarian sphere, the government takes the lead in the establishment of deposit protection institutions, spends public funds on the creation and current operation of deposit protection schemes and serves as a back-stop or lender of the last reserve. These similarities justify my approach to tackling deposit protection as related to merit goods and public interest. In particular, I wish to find out whether the outcomes of the deposit insurance scheme are attributable to erroneous public choice with its regard, or flawed implementation, or both.

The rest of the text is organized in the following way. Section 2 focuses on the theoretical aspects of deposit guaranteeing in the context of social interest and government paternalism. Section 3 sheds light on the drivers of deposit introduction in Russia. Section 4 discusses how paternalistic rhetoric covers up wealth redistribution resulting from deposit guarantee operation. Section 5 views deposit protection within a broader context of institutional change. Section 6 concludes.

\section{Public interest, government and deposit guarantee}

Economic theory provides a broad idea of merit goods as those whose consumption is in line with long-term public interest because their integral social utility exceeds the sum of individual utilities at present. The government is therefore prepared to finance a certain level of merit goods consumption regardless of current market demand for them. It is up to the government to determine the socially desirable level of merit goods consumption (Musgrave, 1987). There is no universally recognized list of goods and services eligible to receive merit goods treatment. Those related to human development, such as education or culture, are natural candidates. This list is however not exhaustive and open to new entries such as national defence etc., according to public choice.

\footnotetext{
${ }^{1}$ Hereinafter I use terms «deposit insurance», «deposit guarantee» and «deposit protection» interchangeably.
} 
What does deposit insurance have to do with public interest or merit goods? It is not immediately clear which specific social need is met in this sphere that would justify a normative consumption standard for this service.

Banking and finance literature treats the deposit guarantee in connection with bank liquidity and systemic risk. Any bank relying on funds received from depositors faces the risk of a depositor run, or massive simultaneous withdrawal of deposits, triggered by an array of possible events or by human expectations. A run is probable to cause bank failure because its funds are invested in longer-term assets such as loans which cannot be immediately liquidated. Bank failure resulting from a depositor run inflicts damage on all parties concerned and unrelated parties alike. The big idea about deposit protection ${ }^{2}$ is to avoid high social cost by safeguarding banks from a depositor run (Bryant, 1980; Diamond, Dybvig, 1983; Keely, 1990; Calomiris, 1999; Allen et al., 2015). The theoretical rationale for deposit protection thus presumes irrational behavior of individuals, which also serves as one of the main assumptions for the traditional theory of merit goods (Musgrave, 1987), as well as contemporary concepts of state paternalism (Kapeliushnikov, 2015; Rubinstein, 2016). Irrationality in this particular case consists in the depositors' propensity to panic that makes them withdraw deposits from a bank in case of doubt or insecurity, not necessarily for a good reason. Contagion effect is associated with depositors' herd behavior.

Market discipline imposed by depositors on a bank (Demirgüç-Kunt, Huizinga, 2004) presumes rationality that requires depositors to withdraw their funds without delay from a bank whose assets become too risky or whose financial condition worsens. Explicit deposit protection affects a depositor's decision-making, whether to keep or to remove funds in the bank account. A credible guarantee from a governmental agency gives additional comfort to depositors who now face smaller potential losses, and to banks which now are fearless of a possible run on them. A guarantee makes depositors less likely to panic and more likely to keep the bank deposit. It is consistent with the «nudging» concept of Richard Thaler in the sense that irrational choice occasionally made by an individual can be influenced and the individual «nudged» toward «correct» behavior. It implies offering the individual a choice rather than coercing him/her (Thaler, Sunstein, 2003). This concept is related to recent advances of experimental economics and behavior economics and, in turn, underpins modern theories of paternalism. One should note that the negative perception of bank soundness can actually be right. In such a case, deposit guarantee becomes a mechanism that bends rationality, suppresses a natural reaction by economic agents and erodes market discipline.

Merit goods theory implies that individuals lack information, resources or willingness to appreciate the value of one or another good or service that the government deems valuable for them, especially in the longer run. In our case, the information relates to bank quality. A frequently invoked argument denies the capability of a «layperson» who lacks knowledge in finance to assess the creditworthiness of a bank bidding for deposits. This argument appears flawed and counter-factual. Differently from «trust goods» whose quality is unknown beforehand, the quality of a bank and thus the depositor's risk can be assessed with some accuracy. In the age of Internet, one can obtain relevant information easily and at no cost. Bank financial reporting is available and publicly accessible, and its quality grows over time. There are many indirect signals of bank risk such as offered interest rates on deposits above the market average. Depositors perceive interest rate offered by the banks as a reflection of the unobservable risk of banks: the weaker the bank, the higher interest rate it offers (Ungan et al., 2008; Karas et al., 2010). There should be more than a reasonable doubt in the soundness of a bank offering above-the-market interest rate on deposits.

Federal deposit insurance emerged in the USA in 1933 at the initiative of President Roosevelt as part of his New Deal package. By that time economic theory was still in the process of constructing a rationale for government involvement in private deposit relations, and seminal theoretical papers on this subject came out much later. 
Another argument is whether depositors should want to obtain information on bank quality, rather than presume sufficient creditworthiness of every active bank with a valid license, in the same way as sufficient aircraft safety is presumed when flying with a legally operating carrier. My answer to that would be, Yes, they should. While 'Customer beware' principle is irrelevant to technical standards and requirements, airline customers do discriminate between airlines according to their record in safety, accuracy, transparency etc. Bank customers should be able to discriminate between banks quality-wise in order to discipline them effectively; otherwise banking would be a public utility and no longer a competitive market-based industry.

It is important to be precise about the content of public interest in this particular sphere. Social utility function that deposit guarantee is to perform includes mobilization of household savings into the financial sector and prevention of a systemic banking crisis originating from depositors' mistrust of their banks. Minimization of losses borne by individual depositors and their switching costs when changing banks remain in depositors' private utility function. But financial instability is detrimental to society as a whole. The society justifies interference in the area of private savings in order to mitigate the negative effects of bank failures. The continuous flow of household savings into the banking sector can be deemed as an issue of ultimate public interest that deserves public monitoring and coordination. The objective is achieved via a state-sponsored system of deposit guarantee. This is how one of the banking services, namely deposit-taking and safe-keeping, sneaks into the category of merit goods or patronized goods, although originally it was a matter of liquidity risk management at privately-owned banks. De facto and de jure, the stability of household deposits held at commercial banks becomes a matter of public interest which is financed by public resources, quite similarly to merit goods in the humanitarian sphere related to human well-being.

The nature of merit good implies that society makes a conscious choice regarding its distribution and consumption. Deposit insurance is introduced via an ordinary legal process, but subsequent public expenditure can be allocated by executive order which evades parliamentary scrutiny. The Central Bank of Russia (CBR) injected funds in the deposit insurance system in anticipation of its insolvency in 2015-2016, and this allocation took the form of a loan bypassing regular budgetary procedure through which public spending normally goes. There is no ceiling on the amount of public funds that can be injected in this way into the deposit insurance system.

The worldwide spread of deposit insurance resulted from external and internal political pressures (Demirgüç-Kunt et al., 2008). Deposit protection has firmly become an element of government bank regulation (Bart et al., 2013). The government can play a variety of roles in respect of a deposit protection scheme. Strictly speaking, the scheme itself needs not to be governmental in terms of funding and administration. Economic history offers broad evidence of private or predominantly private deposit guarantee schemes since the nineteenth century in the USA. It also offers rich evidence of failure and insolvency of such private schemes resulting from mismanagement or fraud («deposit stealing») or both (Thies, Gerlowski, 1989; Hogan, Johnson, 2016; Calomiris, Jaremski, 2018). Very few, if any, of contemporary advanced economies have avoided government involvement in deposit protection (Demirgüç-Kunt et al., 2015).

Mainstream economists representing a variety of schools and paradigms seem to accept and tolerate state-run deposit protection, despite ritual criticism of 'moral hazard' that it creates. Libertarian-minded economists, however, argue that explicit and implicit costs of government engagement in deposit guarantee exceed benefits and that the government should refrain from financing deposit guarantee systems which must be private and voluntary (Hogan, Luther, 2014; Hogan, Johnson, 2016; Hogan, Luther, 2016).

It has been proven both theoretically and empirically that deposit guarantee undermines market discipline and spreads «moral hazard» among individuals and their banks 
(Demirgüç-Kunt, Huizinga, 2004; Allen et al., 2015; Calomiris, Jaremski, 2018). Households whose deposits are guaranteed lose interest in the activity and financial soundness of their banks. It weakens market discipline, i.e. the readiness and willingness of depositors to "punish» their banks by deposit outflow for reckless practices (Martínez-Pería, Schmukler, 2001), while at the same rewarding infantilism and opportunism.

The intensity of the moral hazard effect depends less on the mere fact of deposit guarantee, but on the specific parameters of the system that vary across countries. World Bank introduced a composite safety net index (SNI) to gauge the generosity of national deposit insurance systems depending on the degree of protection and comfort it offers depositors (Demirgüç-Kunt et al., 2015). SNI replaced moral hazard index (Demirgüç-Kunt et al., 2008). More commonly, the generosity of a deposit protection scheme is gauged by the ratio of coverage limit to annual GDP per capita or average salary.

\section{Did paternalism drive deposit guarantee introduction in Russia?}

Political justification of deposit protection often applies to the need of looking after small savers or «laypeople». The Russian case is no different. In the words of a very senior banking supervision official in the 1990s, «ordinary bank customers are a passive majority, and their material interests must be protected not only out of general humanity, but also in order to ensure banking system stability» (quoted from: Krotov, 2009: 77).

The expectation that government will take care, render help and patronage has long driven the mass consciousness of Russians, together with the willingness to delegate responsibility for own actions to someone else (Nureyev, Latov, 2017: 167). Savings behavior has also been shaped by paternalism. During the communist period, savings could be kept at the state-owned institution. After the start of economic transition in 1991, the share of the main savings bank (Sberbank) in household deposits went into a decline as clients were discovering newly-born private banks. It nevertheless stayed above 50 percent, primarily due to a blanket government guarantee.

The first attempts to enact formal deposit protection in Russia date back to the first half of the 1990s (Krotov, 2009), although it did not happen before the end of 2003. Neither the financial wing of the government nor the CBR initiated the public debate on deposit guarantee; a small group of Parliament members did, with support from some experts, bank lobbyists, foreign central bankers and governments and international institutions (Vernikov, 2019). Publicly announced objectives included protection to savers, conversion of saving stock from cash into bank money, inflow of funds into banks, particularly private ones, dissipation of widespread mistrust of private banks, upgrade of their competitiveness, erosion of the Sberbank monopoly, and even a purge of the banking industry (Krotov, 2009). One may reasonably detect subjective motivation such as well-intentioned desire to simulate the institutions of so-called «advanced countries», or to open up a new sphere of activity for the pioneers of deposit protection (which actually worked that way) (Vernikov, 2019). If the objective were merely macroeconomic (to convert savings from cash into bank money), it could have been achieved by the state-owned depository institution (Sberbank) without extension of guarantees to would-be depositors of private banks. Household deposits stayed at Sberbank, i.e. under government guarantee, while deposits at private banks were relatively small.

Objective economic circumstances, however, did not demand immediate adoption of deposit insurance. In the 1990s, the financial issues of most significant concern for households were: the loss of savings due to hyperinflation, the rapid depreciation of the domestic currency, and the fraudulent activity of Ponzi-like schemes. Bank deposit guarantee was unable to address either of these concerns. Nevertheless, the concept of deposit protection appeared as an alternative to the chaos and destruction caused by unrestrained ersatz market and the financial losses suffered by the population. The topic of "protection to ordinary savers and concern about their interest» invariably had good acceptance 
among voters. This topic was present in election materials of one of the leading pioneers of the deposit guarantee. Populist-minded politicians from opposition parties also raised this issue (Krotov, 2009: 105, 244).

The design of the Russian deposit protection scheme reflected social demand for more protection and patronage by the government. The scheme is administered by a statutory stare corporation «Deposit Insurance Agency» (DIA); membership is compulsory for all deposit-taking institutions; each bank is insured separately; within coverage limit, the deposit is to be reimbursed in full; the government co-funds the deposit insurance system and serves as a backstop in case of resource scarcity. The deposit protection scheme is relatively generous. The ratio between the coverage limit and average monthly salary (around *32) exceeds the level of * 20 that is deemed as notionally optimal. The ratio of coverage limit to annual GDP per capita leans towards 200 percent and is regularly adjusted after deviating from this level.

The chosen parameters maximize government involvement and depositor comfort. Russia chose these parameters of deposit insurance independently because it had no international obligations in this field, unlike European transition economies that had to implement the European Acquis Communautaire in full as part of the conditionality for EU admission.

That being said, paternalistic rhetoric served mostly as a smoke-screen to another motivation of the champions of deposit protection. The true thrust of the new institution was to fund new private banks with household savings and to break up the monopoly of Sberbank. This goal was unachievable without a critical trust-building instrument because the new banks did not enjoy such trust on a stand-alone basis (Vernikov, 2019). Protection to certain market participants at the expense of other market participants is an unusual mission for deposit protection. It departs from the core objective of serving as a safety net for sound banks in the face of external liquidity shocks. In Russia, it became rather a confidence booster for unsound banks (Vernikov, 2018). Deposit guarantee was effective in fostering an inflow of private funds to private banks. The market share of private banks reached its peak of 35 percent. That effect only lasted for a few years until the next period of financial turbulence in 2008. The trust of households towards private banks remains low, but under the effect of government guarantee depositors now do not mind placing their funds with these institutions (Ibragimova et al., 2015). They, however, prefer to keep the amounts within coverage limits.

\section{Paternalism as a precursor of wealth redistribution}

The design of any insurance scheme implies redistribution on the ground of solidarity. Redistribution is one of the main forms of economic organization, and this type of economic systems existed long before the rise of market-based societies (Polanyi, 2001). Deposit insurance is also associated with wealth redistribution. Experienced experts at the government and the CBR had warned that premature passage of deposit protection would commit the contributions of sound banks to the depositors of unsound ones (Krotov, 2009). The depositors of privately-owned banks benefit the most from the existence of deposit guarantee by collecting relatively high-interest revenue on their placements without paying a realistic premium for the related risk. 0ther stakeholders of the same banks, primarily their owners and top managers, benefit too by gaining access to funding sources which would otherwise be unavailable to them. The depositors of state-owned and foreign-owned banks, conversely, systematically collect less interest revenue from their banks that make compulsory contributions to the deposit insurance fund.

The intentional misuse of the deposit insurance institution contributed to its redistributive effect. Deposit protection in Russia reallocated wealth from «good» bank depositors to «bad» bank depositors, from sound banks to unsound ones, and from the government 
to other actors. State-owned and foreign-owned banks and their respective depositors are actually net sponsors of the deposit insurance system. During the «honeymoon» of the system while there was little demand for its resources, state-owned banks still contributed most of the DIA incomes due to the fact that the market share of these banks exceeded one-half and currently amounts to three-quarters. Several large-scale bank failures in a row have occurred since 2015 , leading to huge compensation payments to affected depositors and a depletion of the deposit insurance fund. DIA needed additional resources and borrowed RUB 842 billion from $\mathrm{CBR}^{3}$ in order to afford further payments to bank depositors. Deposit insurance is thus an open circuit that requires injections of external (public sector) resources to keep running. Its cumulative expenses (RUB 1,923 billion) by far exceed bank contributions over the same period, RUB 808 billion (Fig. 1). Over 4 million depositors received compensation totaling RUB 1.95 trillion since the inception of the $\mathrm{DIA}^{4}$. Practically all of the 506 insurance cases involved privately-owned banks. Bank insiders take advantage of private customer funds to lend to related parties, cover losses or outright steal deposits.

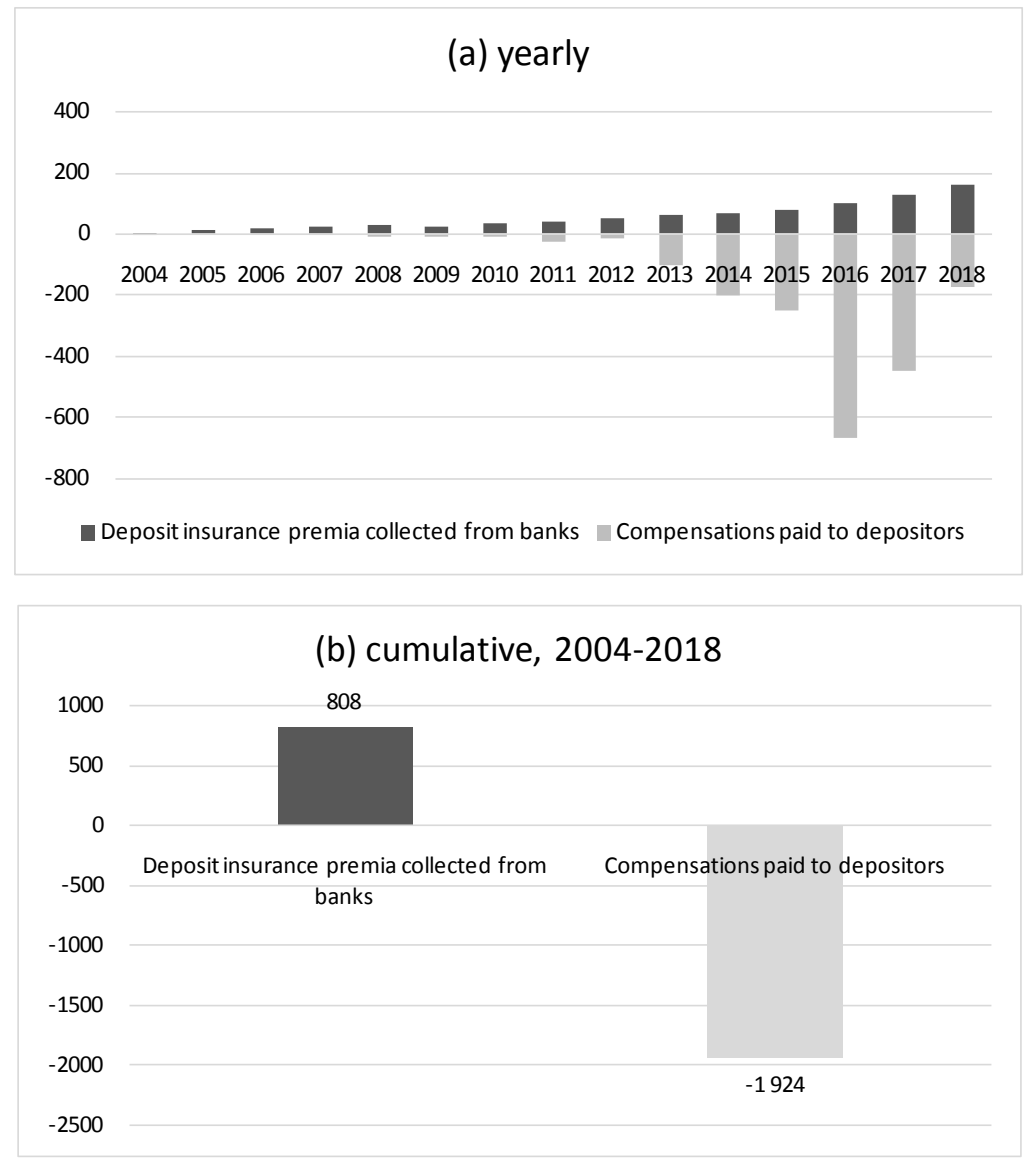

Fig. 1. Bank contributions to deposit insurance fund and payments to depositors, RUB bn

Source: Deposit Insurance Agency ${ }^{5}$; own calculation.

My calculation suggests that the magnitude of gross wealth redistribution through deposit insurance system varies between 0.1 percent of annual GDP (2013) and 0.7 percent (2016). The bail-out loan from CBR to DIA is fully recoverable over time, however, its

\footnotetext{
${ }^{3}$ https://www.asv.org.ru/agency/for_press/pr/613325/

${ }^{4} \mathrm{https}: / /$ www.asv.org.ru/agency/statistical_information/

${ }^{5}$ Based on the annual reports by DIA (https://www.asv.org.ru/agency/\#annual).
} 
net present value is negative due to its long maturity and low (submarket) interest rate. It is therefore a net loss of public funds which is not accounted as such in the public finance books.

This above estimate of gross wealth redistribution caused by deposit protection is on the low side because DIA statistics only cover DIA-insured bank failures and disregards similar cases involving large banks which are handled by the CBR and its Banking Sector Consolidation Fund, bypassing DIA («Otkrytie», B\&N Bank, Promsvyazbank, and TRUST). These cases consumed CBR resources comparable with those spent by DIA ${ }^{6}$. A certain part of these resources, varying from one case to another, was also spent on payouts to private depositors. DIA applies best effort to recover assets stripped off bank balance sheets before failure, but the rate of recovery is far below 50 percent.

The cliché is that deposit insurance primarily protects small savers ('the ordinary people'). In Russia, the coverage limit (RUB 1.4 million) is seven times greater than the average size of household deposit nationwide (RUB 200,800). The latter varies hugely across regions: the city of Moscow leads with RUB 822,000, while several regions report average deposits of less than RUB 50,0007. According to the World Bank, 24 percent of the adult population in Russia do not have a banking account at all ${ }^{8}$, not to mention term deposits. The average size of actually paid deposit insurance grew from RUB 66,000 in 2005 to RUB 634 and 528 in 2017 and 2018, respectively ${ }^{9}$, which is hardly typical of the smallest savers by national standards. This suggests that mass affluent in big cities benefit the most from formal deposit protection, but not «small savers» nor the most vulnerable households.

The operation of the deposit guarantee scheme is ultimately co-funded by its participants and the rest of the society, including people with small or no savings at all. On the other hand, social groups such as private bank depositors and insiders reaped most of the benefits of participating in a deposit protection scheme, judging by the blatant disproportion between funds received from and those contributed to the deposit insurance system. These groups achieved a redistribution of public wealth in their favor and exploited the society at large. The capability of a social group to extract disproportional benefits from the operation of an institution serves as a ground to qualify such an institution as «extractive», in the wording of Acemoglu and Robinson (2012).

\section{Deposit guaranteeing in the context of institutional change}

The formal deposit guarantee is a relatively new institution for Russia. Before 2003, informal institutions were playing the same or similar role. All deposits in Sberbank, by far the most significant savings entity, were announced to be guaranteed by the government. The credibility of the government's commitment was questionable, given the unavailability of needed funds in the budget. Following the crisis of 1998, Sberbank also faced a kind of depositor run (Pyle et al., 2012), albeit triggered by Ruble depreciation concerns rather than the viability of the bank itself. During the same period, the government acted in a paternalistic way by paying partial compensations to the depositors of failed large («oligarchic») banks (Krotov, 2009), in the absence of any explicit legal liability or deposit protection scheme.

The traditions of government paternalism and redistribution of wealth have deep roots in Russia (Kirdina, 2001; Nureyev, Latov, 2017). By the early 1990s, when deposit protection topic emerged, the institutional balance had swiftly shifted, as protectionist and paternalistic institutions were suppressed by deliberate government policies, leaving space to individualism and social Darwinism. The government stopped caring about its citizens. Millions of people lost money in Ponzi-like fraudulent schemes and no longer trusted anyone, including newly-emerged commercial banks. That was unsustainable. Social preferences soon started shifting back to greater social protection and government intervention.

\footnotetext{
${ }^{6}$ The rehabilitation of TRUST cost the CBR at least RUB 127 billion (USD 2.3 billion at the then exchange rate).

${ }^{7} \mathrm{https} / / /$ ria.ru/20191125/1561126844.html?

${ }^{8} \mathrm{https} / / /$ globalfindex.worldbank.org/

${ }^{9}$ Calculated by the author using DIA data.
} 
Deposit insurance became one of the many institutions transplanted into Russia over the 1990s and 2000s. The borrowing of foreign institutions is associated with various risks and negative effects, such as institutional conflict, blockage, rejection, «capture» by interest groups, mutation, or misuse (North, 1997; Rodrik, 2000). Institutional change in Russia also provides such evidence (Roland, 2004; Polishchuk, 2008). Deposit guarantee differs from the absolute majority of other transplanted institutions by its explicitly paternalistic and protectionist thrust. As a result, deposit protection is in line with Russia's historical tradition, which ensured it a good fit and easy adaptation to the local institutional setup. The fit was, perhaps, too good because the counter-balancing institutions of personal responsibility and market discipline remain underdeveloped. In an advanced market economy, deposit guarantee counter-balances the institutions of free market and competition. Deposits stay at privately-owned banks, and the government creates a safety net for banks and depositors. Russia could have followed suit under one important condition that was never met: that state-owned banks leave household deposits market. There have been initiatives to privatize Sberbank in the 1990s and later, in line with what happened to the other 'spetsbanki' (special-purpose state-owned banks) of the former Soviet Union (Schoors, 2003). Those initiatives did not fly. State-owned banks controlled 75 percent of household deposits by 1 January 2019 (the author's calculation based on CBR, 2019). Deposit guarantee duplicates the already existing liability of the government for state-owned banks.

Soon after its formal passage, deposit insurance involved more than 1,000 banks each of which attracted new customers, setting a broad support base for the new institution. Millions of individuals have been directly affected by the operation of the deposit protection scheme. 9.4 million depositors had claims on banks whose failure was insured (DIA data at end-2019). Vast amounts of money from various sources (RUB 2,120 billion cumulatively) have flown through deposit insurance fund. The beneficiaries of deposit insurance have had ample opportunity to promote their interests in all relevant fields. Engaged politicians and lobbyists on behalf of private banks and DIA itself bid for ever-expanding deposit insurance with a higher safety-net index. The system has indeed been evolving in the direction of greater government liability and bank customer safety. The coverage limit has been adjusted four times upwards from RUB 100,000 to RUB 1,400,000. The share of potentially reimbursable deposits grew from 25 percent in 2004 to 69 percent currently. Proportional (partial) reimbursement of insured deposits ( 90 percent of the amount exceeding RUB 100,000) existed for a limited time and was banned in 2008 as presumably ineffective, although it distributes risks more fairly between depositors and the government.

The coverage by deposit guarantee has been creeping to include the deposits by microbusinesses, the funds in escrow accounts for real estate purchase, certificates of deposits. From time to time, lobbyists initiate the debate on further mission creeps of the deposit insurance system. References are made to the US practice where all deposits are FDIC insured. Russian practice offers no evidence of reversal of deposit insurance coverage nor depositor safety. Evolution goes linearly in one direction.

Deposit protection jointly with mass-scale bank rehabilitation changed the behavior patterns of depositors who are now less prone to panic. On the other hand, depositors lost interest in the financial condition of the bank to which they entrust their savings (Chernykh, Cole, 2011). This «numbing» effect stays even during financial turbulence (Karas et al., 2013). Depositors' behavior challenges the theoretical assumption about their inability to assess their bank risk. Instead, they opportunistically-albeit rationallymaximize the return on their placements while staying within coverage limit. There is solid empirical proof that potential loss is reimbursable. A category of «serial depositors» emerged who repeatedly choose the riskiest banks and collect full compensations after those banks fail. Agents affected by the operation of deposit insurance become accustomed to paternalistic protection. We might witness here cultural inertia reinforcing the new institution (Polterovich, 2005). 
In sum, the impact of deposit guarantee on institutional change in Russia can be seen in the fostering of traditions of paternalism and redistribution. Citizens tend to off-load onto the authorities the responsibility for their own financial decisions. Weaker financial discipline is potentially harmful for market efficiency and soundness.

\section{Conclusion}

The theoretical justification of deposit protection is consistent with the concepts of merit goods (Musgrave, 1987), patronized goods (Rubinstein, 2016) and other theories explaining government paternalism. These theories presume that human behavior is irrational. While deposit-taking is supposed to be a private issue between banks and their customers, in the real world household deposits are treated as a patronized service, deservedly or not. Contemporary governments lead the establishment of deposit protection schemes and spend public funds to ensure those schemes' solvency, presumably in order to avoid greater yet social cost resulting from bank failures.

Although formal deposit protection was an alien institution from a different cultural background, it easily fits the Russian setting, which I attribute to deep roots of paternalistic relations. Never mind the rhetoric, the true thrust of the Russian deposit guarantee scheme context was to support the development of privately-owned banks, at the expense of state-owned ones.

Deposit insurance led to a redistribution of wealth from the public sector to the private one. While some redistribution was expected and inevitable, its ultimate scale exceeded expectations. Deposit protection has an implicit taxpayer backstop and drags on public funds. Mass-affluent groups in big cities, not the small savers («lay people»), actually benefited most from deposit protection, and so did the insiders of privately-owned banks. The social costs of deposit insurance in Russia could have been smaller under the condition of more careful design and a timelier implementation.

A part of the social cost of deposit protection stems from destructive behavior patterns and moral hazard that it spreads among banks and depositors. Seen from a longer-term perspective, deposit guarantee hinders market-supporting institutions of financial discipline and responsibility, while reinforcing the institutions of government paternalism and wealth redistribution.

The research implication is that, in the absence of strict eligibility criteria for goods and services that need to be patronized by the government, a good or service that, probably, does not belong there can sneak into the same category through public choice influenced by interest groups.

The policy implication of the paper is that the authorities may need to tackle opportunistic behavior at source, i.e. by amending the features of the deposit insurance scheme.

\section{ЛИТЕРАТУРА}

Верников, А. (2018). Гарантирование банковских вкладов в России: нецелевое использование института или его захват? Препринт WP1/2018/01. М.: Изд. дом Высшей школы экономики.

Кротов, Н. (2009). История создания российской системы страхования банковских вкладов. М.: Экономическая летопись.

Кузьминов, Я., Радаев, В., Яковлев, А., Ясин, Е. (2005). Институты: от заимствования к выращиванию (опыт российских реформ и возможности культивирования институциональных изменений) // Вопросы экономики, (5), 5-27. doi:10.32609/00428736-2005-5-5-27

Нуреев, Р., Латов, Ю. (2017). Экономическая история России (опыт институционального анализа). М.: КНОРУС. 
Acemoglu, D., Robinson, J. (2012). Why Nations Fail: The Origins of Power, Prosperity, and Poverty. New York: Crown Business.

Allen, F., Carletti, E., Goldstein, I., Leonello, A. (2015). Moral hazard and government guarantees in the banking industry // Journal of Financial Regulation, 1(1), 30-50.

Barth, J., Caprio, G., Levine, R. (2013). Bank regulation and supervision in 180 countries from 1999 to 2011 // Journal of Financial Economic Policy, 5(2), 111-219. doi: $10.1108 / 17576381311329661$

Bryant, J. (1980). A model of reserves, bank runs, and deposit insurance // Journal of Banking and Finance, 4(4), 335-344.

Calomiris, Ch. (1999). Building an incentive-compatible safety net // Journal of Banking and Finance, 23(10), 1499-1519.

Calomiris, Ch., Jaremski, M. (2018). Stealing deposits: Deposit insurance, risk-taking, and the removal of market discipline in early $20^{\text {th }}$ century banks // Journal of Finance, 74(2), 711-754. doi: 10.1111/jofi.12753

Chernykh, L., Cole, R. (2011). Does deposit insurance improve financial intermediation: Evidence from the Russian experiment // Journal of Banking and Finance, 35(2), 388-402.

Demirgüç-Kunt, A., Huizinga, H. (2004). Market discipline and deposit insurance // Journal of Monetary Economics, 51, 375-399.

Demirgüç-Kunt, A., Kane, E., Laeven, L. (2008). Determinants of deposit insurance adoption and design // Journal of Financial Intermediation, 17, 407-438.

Demirgüç-Kunt, A., Kane, E., Laeven, L. (2015). Deposit insurance around the world: A comprehensive analysis and database // Journal of Financial Stability, 20, 155-183.

Diamond, D., Dybvig, Ph. (1983). Bank runs, deposit insurance, and liquidity // Journal of Political Economy, 91(3), 401-419.

Dworkin, G. (2019). «Paternalism» / In: E. N. Zalta (ed.) The Stanford Encyclopedia of Philosophy (Fall 2019 Edition) (https://plato.stanford.edu/archives/fall2019/entries/paternalism/ - accessed on January 192020.

Hogan, T., Luther, W. (2014). The explicit costs of government deposit insurance // Cato Journal, 34(1), 145-170.

Hogan, T., Johnson, K. (2016). Alternatives to the Federal Deposit Insurance Corporation // Independent Review, 20(3), 433-454.

Hogan, T., Luther, W. (2016). The implicit costs of government deposit insurance // Journal of Private Enterprise, 31(2), 1-13.

Ibragimova, D., Kuzina, 0., Vernikov, A. (2015). Which banks do Russian households (dis-) trust more? pp. 548-556 / In: Ye. Yasin (ed.) XV April International Academic Conference on Economy and Society, vol. 4. M.: HSE Publishing House.

Kapeliushnikov, R. (2015). Behavioral economics and new paternalism // Russian Journal of Economics, 1(1), 81-107.

Karas, A., Pyle, W., Schoors, K. (2010). How do Russian depositors discipline their banks? Evidence of a backward bending deposit supply function // Oxford Economic Papers, 62(1), 36-61.

Karas, A., Pyle, W., Schoors, K. (2013). Deposit insurance, banking crises, and market discipline: Evidence from a natural experiment on deposit flows and rates // Journal of Money, Credit and Banking, 45(1), 179-200.

Keely, M. (1990). Deposit insurance, risk and market power in banking // American Economic Review, 80(5), 1183-1200.

Kirdina, S. (2014). Institutional matrices theory or X\&Y theory: The main provisions and applications // Journal of Institutional Studies, 6(3), 14-33. 
Martínez-Pería, M.-S., Schmukler, S. (2001). Do depositors punish banks for bad behavior? Market discipline, deposit insurance, and banking crises // Journal of Finance, 56(3), 1029-1051.

Musgrave, R. (1987). «Merit goods», pp. 452-453 / In: The New Palgrave: A Dictionary of Economics, vol. 3.

North, D. (1990). Institutions, Institutional Change and Economic Performance. Cambridge: Cambridge University Press.

Polanyi, K. (2001). The Great Transformation: The Political and Economic Origins of Our Time. Boston: Beacon Press.

Polishchuk, L. (2008). Misuse of institutions: Patterns and causes // Journal of Comparative Economic Studies, 4, 57-80.

Polterovich, V. (2005). Institutional traps: is there a way out? // Social Sciences, 36(1), pp. 30-40.

Pyle, W., Schoors, K., Semenova, M., Yudaeva, K. (2012). Depositor behavior in Russia in the aftermath of financial crisis // Eurasian Geography and Economics, 53(2), 267-285.

Rodrik, D. (2000). Institutions for high quality growth: What they are and how to acquire them // Studies in Comparative International Development, 35(3), 3-31.

Roland, G. (2004). Understanding institutional change: Fast-moving and slow-moving institutions // Studies in Comparative International Development, 38, 109-131. doi:10.1007/BF02686330

Rubinstein, A. (2016). Theory of patronized goods. Liberal evolution of paternalism // International Journal of Entrepreneurial Knowledge, 4(1), 6-29.

Schoors, K. (2003). The fate of Russia's former state banks: Chronicle of a restructuring postponed and a crisis foretold // Europe-Asia Studies, 55(1), 75-100.

The Central Bank of the Russian Federation, CBR (2019). Banking Supervision Report 2018. Moscow: Central Bank of Russia.

Thaler, R., Sunstein, C. (2003). Libertarian paternalism // American Economic Review, 93(2), 175-179.

Thies, C., Gerlowski, D. (1989). Deposit insurance: A history of failure // Cato Journal, 8(3), 677-693.

Ungan, E., Caner, S., Özyıldırım, S. (2008). Depositors' assessment of bank riskiness in the Russian Federation // Journal of Financial Services Research, 33(2), 77-100.

Vernikov, A. (2019). The drivers of institutional change in a post-socialist economy: The case of deposit insurance introduction in Russia // Journal of Institutional Studies, 11(1), 129-143. doi: 10.17835/2076-6297.2019.11.1.129-143

\section{REFERENCES}

Acemoglu, D., Robinson, J. (2012). Why Nations Fail: The Origins of Power, Prosperity, and Poverty. New York: Crown Business.

Allen, F., Carletti, E., Goldstein, I., Leonello, A. (2015). Moral hazard and government guarantees in the banking industry. Journal of Financial Regulation, 1(1), 30-50.

Barth, J., Caprio, G., Levine, R. (2013). Bank regulation and supervision in 180 countries from 1999 to 2011. Journal of Financial Economic Policy, 5(2), 111-219. doi: 10.1108/17576381311329661

Bryant, J. (1980). A model of reserves, bank runs, and deposit insurance. Journal of Banking and Finance, 4(4), 335-344.

Calomiris, Ch. (1999). Building an incentive-compatible safety net. Journal of Banking and Finance, 23(10), 1499-1519. 
Calomiris, Ch., Jaremski, M. (2018). Stealing deposits: Deposit insurance, risk-taking, and the removal of market discipline in early $20^{\text {th }}$ century banks. Journal of Finance, $74(2)$, 711-754. doi: 10.1111/jofi.12753

Chernykh, L., Cole, R. (2011). Does deposit insurance improve financial intermediation: Evidence from the Russian experiment. Journal of Banking and Finance, 35(2), 388-402.

Demirgüç-Kunt, A., Huizinga, H. (2004). Market discipline and deposit insurance. Journal of Monetary Economics, 51, 375-399.

Demirgüç-Kunt, A., Kane, E., Laeven, L. (2008). Determinants of deposit insurance adoption and design. Journal of Financial Intermediation, 17, 407-438.

Demirgüç-Kunt, A., Kane, E., Laeven, L. (2015). Deposit insurance around the world: A comprehensive analysis and database. Journal of Financial Stability, 20, 155-183.

Diamond, D., Dybvig, Ph. (1983). Bank runs, deposit insurance, and liquidity. Journal of Political Economy, 91(3), 401-419.

Dworkin, G. (2019). «Paternalism» / In: E. N. Zalta (ed.) The Stanford Encyclopedia of Philosophy (Fall 2019 Edition) (https://plato.stanford.edu/archives/fall2019/entries/paternalism/ - accessed on January 192020.

Hogan, T., Luther, W. (2014). The explicit costs of government deposit insurance. Cato Journal, 34(1), 145-170.

Hogan, T., Johnson, K. (2016). Alternatives to the Federal Deposit Insurance Corporation. Independent Review, 20(3), 433-454.

Hogan, T., Luther, W. (2016). The implicit costs of government deposit insurance. Journal of Private Enterprise, 31(2), 1-13.

Ibragimova, D., Kuzina, 0., Vernikov, A. (2015). Which banks do Russian households (dis-) trust more? pp. 548-556 / In: Ye. Yasin (ed.) XV April International Academic Conference on Economy and Society, vol. 4. M.: HSE Publishing House.

Kapeliushnikov, R. (2015). Behavioral economics and new paternalism. Russian Journal of Economics, 1(1), 81-107.

Karas, A., Pyle, W., Schoors, K. (2010). How do Russian depositors discipline their banks? Evidence of a backward bending deposit supply function. Oxford Economic Papers, 62(1), 36-61.

Karas, A., Pyle, W., Schoors, K. (2013). Deposit insurance, banking crises, and market discipline: Evidence from a natural experiment on deposit flows and rates. Journal of Money, Credit and Banking, 45(1), 179-200.

Keely, M. (1990). Deposit insurance, risk and market power in banking. American Economic Review, 80(5), 1183-1200.

Kirdina, S. (2014). Institutional matrices theory or X\&Y theory: The main provisions and applications. Journal of Institutional Studies, 6(3), 14-33.

Krotov, N. (2009). The History of the Russian Deposit Insurance System. Moscow: Ekonomicheskaya letopis Publ. (In Russian.)

Kuzminov, Y., Radaev, V., Yakovlev, A., Yasin, Ye. (2005). Institutions: From Import to Raising (Lessons from the Russian Reforms and Opportunities for Cultivation of Institutional Change). Voprosy Ekonomiki, (5), 5-27. doi:10.32609/0042-8736-2005-5-5-27 (in Russian.)

Martínez-Pería, M.-S., Schmukler, S. (2001). Do depositors punish banks for bad behavior? Market discipline, deposit insurance, and banking crises. Journal of Finance, 56(3), 1029-1051.

Musgrave, R. (1987). «Merit goods», pp. 452-453 / In: The New Palgrave: A Dictionary of Economics, vol. 3. 
North, D. (1990). Institutions, Institutional Change and Economic Performance. Cambridge: Cambridge University Press.

Nureyev, R., Latov, Yu. (2017). Economic History of Russia: An Attempt of Institutional Analysis. Moscow: KNORUS. (In Russian.)

Polanyi, K. (2001). The Great Transformation: The Political and Economic Origins of Our Time. Boston: Beacon Press.

Polishchuk, L. (2008). Misuse of institutions: Patterns and causes. Journal of Comparative Economic Studies, 4, 57-80.

Polterovich, V. (2005). Institutional traps: is there a way out? Social Sciences, 36(1), 30-40.

Pyle, W., Schoors, K., Semenova, M., Yudaeva, K. (2012). Depositor behavior in Russia in the aftermath of financial crisis. Eurasian Geography and Economics, 53(2), 267-285.

Rodrik, D. (2000). Institutions for high quality growth: What they are and how to acquire them. Studies in Comparative International Development, 35(3), 3-31.

Roland, G. (2004). Understanding institutional change: Fast-moving and slow-moving institutions. Studies in Comparative International Development, 38, 109-131. doi:10.1007/BF02686330

Rubinstein, A. (2016). Theory of patronized goods. Liberal evolution of paternalism International Journal of Entrepreneurial Knowledge, 4(1), 6-29.

Schoors, K. (2003). The fate of Russia's former state banks: Chronicle of a restructuring postponed and a crisis foretold. Europe-Asia Studies, 55(1), 75-100.

The Central Bank of the Russian Federation, CBR (2019). Banking Supervision Report 2018. Moscow: Central Bank of Russia.

Thaler, R., Sunstein, C. (2003). Libertarian paternalism. American Economic Review, 93(2), 175-179.

Thies, C., Gerlowski, D. (1989). Deposit insurance: A history of failure. Cato Journal, 8(3), 677-693.

Ungan, E., Caner, S., Özyıldırım, S. (2008). Depositors' assessment of bank riskiness in the Russian Federation. Journal of Financial Services Research, 33(2), 77-100.

Vernikov, A. (2018). Deposit insurance in Russia: Was the institution misused or captured?. Working paper WP1/2018/01, Moscow: HSE Publishing House. (In Russian.)

Vernikov, A. (2019). The drivers of institutional change in a post-socialist economy: The case of deposit insurance introduction in Russia. Journal of Institutional Studies, 11(1), 129-143. doi: 10.17835/2076-6297.2019.11.1.129-143 